
and Muhammad Moazzam Naseer

\title{
Synthesis and antimalarial activity of some triphenyltin(IV) aminobenzoate compounds against Plasmodium falciparum
}

https://doi.org/10.1515/mgmc-2021-0028

received May 31, 2021; accepted September 07, 2021

\begin{abstract}
This paper presents antimalarial activity of several triphenyltin(IV) aminobenzoate compounds synthesized from the reaction of triphenyltin(IV) hydroxide with 2-, 3-, and 4-aminobenzoic acid. The activity of the compounds as anti-malaria agents was evaluated using Plasmodium falciparum, and demonstrated that the compounds have about the same $\mathrm{IC}_{50}$ with that of chloroquine $\left(2 \times 10^{-3} \mu \mathrm{g} / \mathrm{mL}\right)$ applied as the positive control. The result also showed that the Plasmodium is non-resistent to the compounds synthesized, which is the opposite to chloroquine.
\end{abstract}

Keywords: antimalarial activity, $\mathrm{IC}_{50}$, triphenyltin(IV) aminobenzoate, P. falciparum

\section{Introduction}

Malaria, a disease originating from Plasmodium, has been the enemy of mankind since hundreds of years back, and remains as a dangerous threat to public health in many tropical countries, including Indonesia. Roll back malaria (RBM) program has been introduced by WHO in an effort to minimize the wider spread of malaria. Some important points of the RBM program were quick diagnoses and right treatment in eradicating malaria (Elyazar et al.,

* Corresponding author: Sutopo Hadi, Department of Chemistry, Faculty of Mathematics and Natural Sciences, University of Lampung, Bandar Lampung-35145, Indonesia,

e-mail: sutopo.hadi@fmipa.unila.ac.id

Mona Dwi Fenska, Noviany Noviany, Heri Satria and

Wasinton Simanjuntak: Department of Chemistry, Faculty of

Mathematics and Natural Sciences, University of Lampung, Bandar Lampung-35145, Indonesia

Muhammad Moazzam Naseer: Department of Chemistry,

Quaid-i-Azam University, Islamabad-45320, Pakistan
2010; WHO, 2005, 2016). In the last ten years, Indonesia has reported sharp increase of malaria cases, reaching ten times increase in the provinces of Java and Bali islands, and 4-5 times in the other provinces around the nation. The situation was worsened by increased cases due to resistance toward standard drugs used, namely the chloroquine and the sulfadoxine-pyrimethamine. In some provinces, resistance cases of more than $25 \%$ were found, reflecting the crucial need to limit the use of standard drugs (Elyazar et al., 2010; WHO, 2005). Because of this situation, the efforts to find new and prospective drugs are challenging and crucial in order to alleviate the problems associated with the use of existing drugs.

Organotin(IV) compounds find many biological applications because they have strong effect even at very low concentration (Szorcsik et al., 2002; Tiekink, 1991). Biological activities of the compounds are primarily dependent on the organic functional groups bound to Sn (Pellerito and Nagy, 2002), and on the anion bearing groups attached to the Sn center as a complementary factor (Pellerito and Nagy, 2002). The recent results from the study on organotin(IV) compounds have demonstrated that several organotin(IV) carboxylates exhibit promising activities as biological agents. Among these are antifungal (Pellerito and Nagy, 2002), antibacterial (Annissa et al., 2017; Hadi et al., 2018a, 2021; Rehman et al., 2009; Samsuar et al., 2021), antitumor and anticancer (Hadi and Rilyanti, 2010; Hadi et al., 2012; Rehman et al., 2009), corrosion inhibitor (Hadi et al., 2015; Hazani et al., 2019; Kurniasih et al., 2015), antioxidant activities (Sari et al., 2020; Tyurin et al., 2015). Moreover, these compounds have been found to exhibit strong activity as antimalarial and antiplasmodial agents (Hadi et al., 2018b, 2019; Hansch and Verma 2009). In this context, it is therefore highly valuable to further explore the potential of organotin(IV) carboxylates for antimalarial treatments.

Triphenyltin(IV) aminobenzoates are important biologically active derivatives of organotin(IV) compounds 
(Holeček et al., 1983; Khoo and Smith, 1981; Molloy et al., 1988; Sandhu et al., 1987; Swisher et al., 1984; Tzimopoulos et al., 2009) that need to be tested for their potential as antimalarial agents. With this in mind, we carried out this study and herein, report the results of antimalarial assays of several triphenyltin(IV) aminobenzoates using P. falciparum as a target.

\section{Results and discussion}

Three triphenyltin(IV) aminobenzoates 2, 3, and 4 (Figure 1) have been synthesized by reacting $\left[\left(\mathrm{C}_{6} \mathrm{H}_{5}\right)_{3} \mathrm{SnOH}\right]$ (1) with 2-, 3-, 4-aminobenzoic acids, respectively using the procedure available in literatures (Hadi and Rilyanti, 2010; Hadi et al., 2012, 2018a, 2021; Szorcsik et al., 2002). The elemental microanalyses of all synthesized compounds are in accordance with the calculated data.

Several spectroscopic techniques were used to confirm the identity of the compounds. The FT-IR spectrum of compound $\mathbf{1}$ is characterized by a strong band at wave number of $726.36 \mathrm{~cm}^{-1}$ indicating the presence of a Sn-O bond. The band at $3437.29 \mathrm{~cm}^{-1}$ is assigned to the $\mathrm{Sn}-\mathrm{OH}$ bond. Upon formation of compound $\left[\left(\mathrm{C}_{6} \mathrm{H}_{5}\right)_{3} \mathrm{Sn}\left(2-\mathrm{OOCC}_{6} \mathrm{H}_{4} \mathrm{NH}_{2}\right]\right.$ (2), for example, the spectrum indicates that the hydroxyl stretching vibration disappeared. Intense bands resulted from asymmetric stretching of the carboxylate group at around $1530 \mathrm{~cm}^{-1}$ and symmetric stretching at around $1634 \mathrm{~cm}^{-1}$, which indicated that the aminobenzoate ligand has bound to the Sn centre and replaced the $\mathrm{OH}^{-}$group in compound 1. Attachment of the ligand to $\mathrm{Sn}$ atom is justified by the emergence of absorption band at $1240 \mathrm{~cm}^{-1}$, which is associated with Sn-O-C stretching. The absorption bands observed in the FTIR spectrum clearly indicated the formation of compound 2 (Hadi et al., 2018a; Holeček et al., 1983; Sudjadi, 1985; Szorcsik et al.; 2002). Similar observations are also true for the formation of compounds $\mathbf{3}$ and $\mathbf{4}$ (Holeček et al., 1983; Khoo and Smith, 1981; Molloy et al., 1988; Sandhu et al., 1987; Tzimopoulos et al., 2009).

The ${ }^{1} \mathrm{H}$ and ${ }^{13} \mathrm{C}$ NMR spectra for the compounds synthesized have been characterized carefully based on some important signals in the spectra obtained. The existence of phenyl protons bound to central atom $\mathrm{Sn}$ is confirmed by chemical shifts in the range of 7.30-7.59 ppm and the protons in benzoate are confirmed by chemical shifts at 7.6-7.9 ppm. Other signals observed in the NMR spectra are those at $\delta$ in the range of $126-131 \mathrm{ppm}$, which represent carbon atoms of the phenyl ligand, and those at $\delta$ in the range of $130-140 \mathrm{ppm}$, which represent the carbons in the aminobenzoate. These values are in good agreements with the literature values (Holeček et al., 1983; Sandhu et al., 1987). Further support was provided by the signals in the region of $163-166$ ppm, which signify the existence of carboxyl group. All chemical shifts obtained for the compounds synthesized are in agreement with the data of previously investigated similar compounds (Hadi et al., 2003, 2012, 2018a, 2021; Hadi and Appleton, 2010; Hadi and Rilyanti, 2010).

The experimental results compiled in Table 1 clearly display that triphenyltin(IV)aminobenzoates exhibit higher antimalarial activity compared to those of diphenyltin(IV) and dibutyltin(IV) derivatives reported in previous publications (Hadi et al., 2018b, 2019). Furthermore, it is worth mentioning here that the triphenyltin(IV) aminobenzoate compounds $\mathbf{2 ,} \mathbf{3}$, and $\mathbf{4}$ are much more active as compared to the ligand (see Table 1) and the other starting material i-e $\left[\left(\mathrm{C}_{6} \mathrm{H}_{5}\right)_{3} \mathrm{SnOH}\right](\mathbf{1})$. The $\mathrm{IC}_{50}$ values of all compounds in the series are quite close and their values are comparable to the reported values for compound isolated from some plants or other synthetic compounds (Hadi et al., 2018b, 2019; Hansch and Verma 2009; Suhartati et al., 2010, 2020). Based on the $\mathrm{IC}_{50}$ values of these compounds, they are categorized as very active compounds, as stated by Widyawaruyanti et al. (2014) that a compound with an $\mathrm{IC}_{50}$ value less than $5 \mu \mathrm{g} / \mathrm{mL}$ was categorized as an active compound in the antimalarial activity test.

Based on the experimental results obtained, it can be outlined that both the nature and type of ligand are important in the activity of triphenyltin(IV) compounds as anti-malarial agents (Chohan and Rauf, 1996). These findings are in agreement with generally acknowledged feature of many biologically active compounds, in which the activity of complex compounds is higher

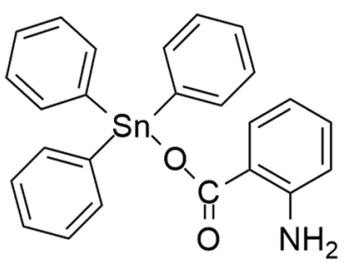

2

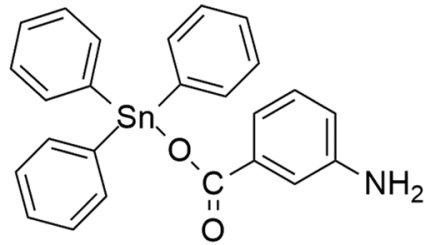

3<smiles>Nc1ccc(C(=O)O[Sn](c2ccccc2)(c2ccccc2)c2ccccc2)cc1</smiles>

4

Figure 1: The structure of the compounds studied. 
Table 1: The $_{\mathrm{IC}}$ of the compounds investigated

\begin{tabular}{lc}
\hline Compounds & $\mathrm{IC}_{50}(\mu \mathrm{g} / \mathrm{mL})$ \\
\hline Chloroquine & $2.0 \times 10^{-3}$ \\
2-aminobenzoic acid $\left(2-\left(\mathrm{NH}_{2}\right)\right.$ & 122 \\
$\left.\mathrm{C}_{6} \mathrm{H}_{4} \mathrm{COOH}\right)$ & \\
{$\left[\left(\mathrm{C}_{6} \mathrm{H}_{5}\right)_{3} \mathrm{SnOH}\right](1)$} & 26 \\
{$\left[\left(\mathrm{C}_{6} \mathrm{H}_{5}\right)_{3} \mathrm{Sn}\left(2-\mathrm{OOCC} \mathrm{H}_{4} \mathrm{NH}_{2}\right](2)\right.$} & $3.7 \times 10^{-3}$ \\
{$\left[\left(\mathrm{C}_{6} \mathrm{H}_{5}\right)_{3} \mathrm{Sn}\left(3-\mathrm{OOCC} \mathrm{H}_{4} \mathrm{NH}_{2}\right](3)\right.$} & $7.7 \times 10^{-3}$ \\
{$\left[\left(\mathrm{C}_{6} \mathrm{H}_{5}\right)_{3} \mathrm{Sn}\left(4-\mathrm{OOCC} \mathrm{H}_{4} \mathrm{NH}_{2}\right](4)\right.$} & $9.1 \times 10^{-3}$ \\
\hline
\end{tabular}

than that of their corresponding uncomplexed forms (Gershon, 1974).

\section{Conclusions}

Three triphenyltin(IV) aminobenzoate compounds have been prepared and tested for their antimalarial activity against $\mathrm{P}$. falciparum. Promising activity as anti-malarial agent was exhibited by the prepared triphenyltin(IV) aminobenzoates, and as a continuation, the study for more comprehensive examination of the activity of these compounds as anti-malarial agent based on artemisin combination therapy (ACT) is now in progress.

\section{Experimental}

\section{Materials}

The chemicals used in this study are reagent (AR) grade obtained from recognized suppliers, and therefore they were used as received. Triphenyltin(IV) hydroxide $\left(\left(\mathrm{C}_{6} \mathrm{H}_{5}\right)_{3} \mathrm{OH}\right)(\mathbf{1}), 2-$, 3-, 4-aminobenzoic acids, and RPMI complete solution were obtained from Sigma-Aldrich (Germany), methanol $\left(\mathrm{CH}_{3} \mathrm{OH}\right)$ was obtained from JT Baker company (United Kingdom). Biological activity tests of the synthesized compounds were evaluated using a positive control compound (commercial chloroquine, obtained from PT. Kimia Farma, Indonesia).

\section{Characterization}

A Shimadzu UV-245 Spectrophotometer (Japan) was utilized to produce the UV spectra, by measuring the samples (1.0×10-4 $\mathrm{M}$ dissolved in methanol), using a $1 \mathrm{~mL}$ quartz-cuvette. Elemental analyser (Carlo Erba (Fisons) EA 1108 CHNS-O Elemental Analyzer, Italy Fisons EA 1108 series) was utilized to determine chemical composition (CHNS) of the samples. FTIR characterization, with Bruker VERTEX 70 FT-IR spectrophotometer (Germany), was conducted using $\mathrm{KBr}$ pellet procedure, generating the spectrum was generated by scanning the sample over the wave number range of $4000-400 \mathrm{~cm}^{-1}$. NMR data $\left({ }^{1} \mathrm{H}\right.$ and ${ }^{13} \mathrm{C}$ spectra) were collected using spectrometer (Bruker $\mathrm{AV}$ $600 \mathrm{MHz}$ NMR spectrometer, Germany) with the frequency of $600 \mathrm{MHz}$ for ${ }^{1} \mathrm{H}$ and $150 \mathrm{MHz}$ for ${ }^{13} \mathrm{C}$. Measurements were run at $298 \mathrm{~K}$ using DMSO-D ${ }_{6}$, with 32 scans for ${ }^{1} \mathrm{H}$ and DMSO signal at $2.5 \mathrm{ppm}$ as a reference and 1000-4000 scans for ${ }^{13} \mathrm{C}$ and the signal at $39.5 \mathrm{ppm}$ as DMSO reference signal. The melting points were determined using Gallenkamp Melting Point Apparatus with maximum temperature range of $300^{\circ} \mathrm{C}$ and were uncorrected.

\section{Preparation of triphenyltin(IV) aminobenzoates}

Preparation of triphenyltin(IV) aminobenzoates was conducted in accordance with the method applied in previous works (Hadi and Rilyanti, 2010; Hadi et al., 2012, 2018a; Szorcsik et al., 2002). A typical experiment to prepare of triphenyltin(IV) 2-aminobenzoate was commenced by dissolving compound $\mathbf{1}(0.5505 \mathrm{~g}$ or $1.5 \mathrm{mmol}$ ) in methanol ( $50 \mathrm{~mL})$, and then mixed with 1 mole equivalent of 2-aminobenzoic acid $(0.206 \mathrm{~g})$, followed by $4 \mathrm{~h}$ refluxing at $60-62^{\circ} \mathrm{C}$, the water was removed using a Dean-Stark apparatus. After the completion of the experiment, solvent removal was conducted using a rotary evaporation, and the solid $\left[\left(\mathrm{C}_{6} \mathrm{H}_{5}\right)_{3} \mathrm{Sn}\left(2-\mathrm{OOCC}_{6} \mathrm{H}_{4} \mathrm{NH}_{2}\right]\right.$ (2) produced was vacuum dried. The mass of the solid obtained was $0.671 \mathrm{~g}$ which is equivalent to $92 \%$ yield. The sample was then analysed and used for in vitro study as antimalarial agent.

Two other compounds, triphenyltin(IV) 3-aminoben zoate, $\left[\left(\mathrm{C}_{6} \mathrm{H}_{5}\right)_{3} \mathrm{Sn}\left(3-\mathrm{OOCC}_{6} \mathrm{H}_{4} \mathrm{NH}_{2}\right)\right]$ (3) and triphenyltin(IV) 4-aminobenzoate, $\left[\left(\mathrm{C}_{6} \mathrm{H}_{5}\right)_{3} \mathrm{Sn}\left(4-\mathrm{OOCC}_{6} \mathrm{H}_{4} \mathrm{NH}_{2}\right)\right]$ (4) were synthesized using the same way as applied in previous experiment to synthesize compound (2).

Triphenyltin(IV) 2-aminobenzoate (2): whiteyellowish solid; $\mathrm{UV} \lambda_{\text {max. }}(\mathrm{MeOH}) \mathrm{nm}(\log \varepsilon): 236$ and 290; IR $v_{\text {max. }}(\mathrm{KBr}) \mathrm{cm}^{-1}: 1633.4$ (COO asym), 1428.7 (COO sym), 729.4 (phen), 1243.4 (Sn-O-C), 365.6 (Sn-O); ${ }^{1} \mathrm{H}-\mathrm{NMR}$ (in DMSO-D $6,600 \mathrm{MHz}) \delta(\mathrm{ppm}): \mathrm{H}_{2}$ and $\mathrm{H}_{6}=7.59(\mathrm{~d}, 6 \mathrm{H}) ; \mathrm{H}_{3}$ and $\mathrm{H}_{5}=7.48(\mathrm{t}, 6 \mathrm{H}) ; \mathrm{H}_{4}=7.35(\mathrm{t}, 3 \mathrm{H})$, $\mathrm{H}$ in benzoate $=\mathrm{H}_{10}=$ $7.84(\mathrm{~d}), \mathrm{H}_{11}=7.65(\mathrm{t})$ and $\mathrm{H}_{12}=7.63(\mathrm{t}), \mathrm{H}_{13}=7.72(\mathrm{~d}) ;{ }^{13} \mathrm{C}-\mathrm{NMR}$ (in DMSO- $\mathrm{D}_{6}, 150 \mathrm{MHz}$ ): $\delta$ (ppm): $\mathrm{C}$ (phen) $\mathrm{C}_{2}$ and $\mathrm{C}_{6}=131.7$, $\mathrm{C}_{3}$ and $\mathrm{C}_{5}=129.3, \mathrm{C}_{4}=126.9 ; \mathrm{C}_{7}=166.7 ; \mathrm{C}_{8}=139.5 ; \mathrm{C}_{9}=133.2$; $C_{10}=129.1 ; C_{11}=128.5 ; C_{12}=128.3 ; C_{13}=130.1 ;$ microelemental analysis: found (calculated): C 61.65 (61.73), H 4.29 (4.32), 
N 2.86 (2.88). M.p. $109-111^{\circ} \mathrm{C}$. Literature values: $108-109^{\circ} \mathrm{C}$ (Khoo and Smith, 1981), 110-112 ${ }^{\circ} \mathrm{C}$ (Molloy et al., 1988), $106-107^{\circ} \mathrm{C}$ (Shandu et al., 1987).

Triphenyltin(IV) 3-aminobenzoate (3): white solid; UV $\lambda_{\text {max. }}(\mathrm{MeOH}) \mathrm{nm}(\log \varepsilon): 236$ and 289; IR $v_{\text {max. }}(\mathrm{KBr})$ $\mathrm{cm}^{-1}: 1630.2$ (COO asym), 1427.6 (COO sym); 728.8 (phen), 1242.8 (Sn-O-C), 363.9 (Sn-0); ${ }^{1} \mathrm{H}-\mathrm{NMR}$ (in DMSO-D ${ }_{6}$, $600 \mathrm{MHz}) \delta(\mathrm{ppm}): \mathrm{H}_{2}=\mathrm{H}_{6} 7.59(\mathrm{~d}, 6 \mathrm{H}) ; \mathrm{H}_{3}$ and $\mathrm{H}_{5}=7.46(\mathrm{t}, 6 \mathrm{H}) ; \mathrm{H}_{4}=7.33(\mathrm{t}, 3 \mathrm{H}), \mathrm{H}$ in benzoate: $\mathrm{H}_{9}=7.83(\mathrm{~s})$; $\mathrm{H}_{11}=7.60$ (d); $\mathrm{H}_{12}=7.60$ (d); $\mathrm{H}_{13}=7.60$ (d); ${ }^{13} \mathrm{C}$-NMR (in DMSO-D 6 , $150 \mathrm{MHz}): \delta$ (ppm): C(phen) $\mathrm{C}_{2}$ and $\mathrm{C}_{6}=131.7, \mathrm{C}_{3}$ and $\mathrm{C}_{5}=129.2, \mathrm{C}_{4}=126.9 ; \mathrm{C}_{7}=165.3 ; \mathrm{C}_{8}=137.2 ; \mathrm{C}_{9}=132.9$; $\mathrm{C}_{10}=129.5 ; \mathrm{C}_{11}=128.4 ; \mathrm{C}_{12}=128.2 ; \mathrm{C}_{13}=130.0$; microelemental analysis: found (calculated): C 61.67 (61.73), H 4.29 (4.32), $\mathrm{N} 2.87$ (2.88). M.p. $105-106^{\circ} \mathrm{C}$. Literature value: $105^{\circ} \mathrm{C}$ (Shandu et al., 1987).

Triphenyltin(IV) 4-aminobenzoate (4): white solid; UV $\lambda_{\text {max. }}(\mathrm{MeOH}) \mathrm{nm}(\log \varepsilon)$ : 236 and 286; IR $v_{\text {max. }}(\mathrm{KBr}) \mathrm{cm}^{-1}$ : 1629.8 (COO asym); 1426.5 (COO sym); 727.6 (phen), 1241.3 (Sn-O-C), 362.8 (Sn-0); ${ }^{1} \mathrm{H}-\mathrm{NMR}$ (in DMSO-D 6 , $600 \mathrm{MHz}$ ) $\delta(\mathrm{ppm}): \mathrm{H}_{2}$ and $\mathrm{H}_{6}=7.57(\mathrm{~d}, 6 \mathrm{H}) ; \mathrm{H}_{3}$ and $\mathrm{H}_{5}=7.45(\mathrm{t}, 6 \mathrm{H})$; $\mathrm{H}_{4}=7.32(\mathrm{t}, 3 \mathrm{H})$, $\mathrm{H}$ in benzoate: $\mathrm{H}_{9}$ and $\mathrm{H}_{13}=7.78(\mathrm{~d}), \mathrm{H}_{10}$ and $\mathrm{H}_{12}=7.80$ (d); ${ }^{13} \mathrm{C}-\mathrm{NMR}$ (in DMSO-D, $150 \mathrm{MHz}$ ): $\delta$ (ppm): $\mathrm{C}$ (phen) $\mathrm{C}_{2}$ and $\mathrm{C}_{6}=131.6, \mathrm{C}_{3}$ and $\mathrm{C}_{5}=129.1, \mathrm{C}_{4}=126.9$; $\mathrm{C}_{7}=163.8 ; \mathrm{C}_{8}=137.0 ; \mathrm{C}_{9}$ and $\mathrm{C}_{13}=130.2 ; \mathrm{C}_{10}$ and $\mathrm{C}_{12}=129.1$; $\mathrm{C}_{11}=129.5$; microelemental analysis: found (calculated): C 61.69 (61.73), H 4.31 (4.32), N 2.88 (2.88). M.p. $157-158^{\circ} \mathrm{C}$. Literature values: $158-159^{\circ} \mathrm{C}$ (Khoo and Smith, 1981), $156-157^{\circ} \mathrm{C}$ (Shandu et al., 1987).

\section{In vitro antimalarial bioactivity assays}

In vitro antimalarial activity evaluations were run in the Institute of Tropical Disease, Universitas Airlangga, Surabaya Indonesia, using P. falciparum 3D7 clone, previously propagated by the procedure reported in literature (Hadi et al., 2018b, 2019; Suhartati et al., 2010, 2020). Propagation was carried out in tissue culture medium contains RPMI-1640, and supplements consist of gentamycin $(25 \mu \mathrm{g} / \mathrm{mL})$, hypoxanthine $(50 \mu \mathrm{g} / \mathrm{mL})$, Hepes buffer $(25 \mathrm{mM})$, sodium bicarbonate $(25 \mathrm{mM}), \mathrm{AB}(10 \%)+$ human serum, haematocrit (5\%), and $\mathrm{pH} 7.4$ human erythrocytes. Solution of test compound in DMSO as a solvent was diluted to different concentrations by addition of specified quantity of the medium for antimalarial assay, with chloroquine as a positive control. Antiplasmodial activity was investigated by placing the parasites in a 24-well culture plate filled with compound to be tested at different concentrations. The growth of parasite was monitored by preparing methanol fixed blood smear and stained with Giemsa. Calculation of total parasitaemia was carried out by dividing the number of observed parasites with erythrocytes total multiplied by $100 \%$. Concentration response of parasite growth was determined from linear regression drawn with the aid of SYSTAT Sigma Plot, using the $50 \%$ inhibitory concentration $\left(\mathrm{IC}_{50}\right)$, which is a concentration of compound capable to supress 50\% growth relative to the growth in the control experiment.

Acknowledgement: The authors are grateful to Institute of Research and Community Services, Universitas Lampung for their help in the administration process in obtaining the research funding.

Funding information: This work was funded by Directorate of Research and Community Services, The Ministry of Research, Technology/Research and National Innovation Agency, Indonesia. that provided fund for this project to be undertaken through Penelitian Dasar and Penelitian Terapan (Basic Research and Applied Research Grant Schemes) 2020 with contract numbers 179/SP2H/ADM/ LT/DRPM/2020 and 139/SP2H/AMD/LT/DRPM/2020, respectively.

Author contributions: Sutopo Hadi: writing - original draft, writing - review and editing, methodology, formal analysis; supervision; project administration; Mona Dwi Fenska: experimental work; Heri Satria: resources, supervision; Wasinton Simanjuntak: formal analysis, resources, visualization; Muhammad Moazzam Naseer: writing - review and editing.

Conflict of interest: One of the authors (Muhammad Moazzam Naseer) is a member of the Editorial Board of Main Group Metal Chemistry.

Data availability statement: The datasets generated during and/or analysed during the current study are available from the corresponding author on reasonable request.

\section{References}

Annissa, Suhartati T., Yandri, Hadi S., Antibacterial Activity of Diphenyltin(IV) and Triphenyltin(IV) 3-Chlorobenzoate against Pseudomonas aeruginosa and Bacillus subtilis. Orient. J. Chem., 2017, 33(3), 1133-1139.

Chohan Z.H., Rauf A., Some Biologically Active Mixed Ligand Complexes of $\mathrm{Co}(\mathrm{II}), \mathrm{Cu}(\mathrm{II})$ and $\mathrm{Ni}(\mathrm{II})$ with ONO, NNO and SNO Donor Nicotinoylhydrazine-Derived Ligands. Synth. React. Inorg. M., 1996, 26, 591-604. 
Elyazar I.R.F., Hay S.I., Baird J.K., Malaria distribution, prevalence, drug resistance and control in Indonesia. Adv. Parasitol., 2010, 74, 41-175.

Gershon H., Antifungal Activity of Bischelates of 5-, 7-, and 5,7-halogenated 8-quinols with copper(II). Determination of the long and short acces of the pores in the fungal spore wall. J. Med. Chem., 1974, 17, 824-827.

Hadi S., Appleton T.G., Ayoko G.A., Reactions of fac-[PtMe ${ }_{2}(\mathrm{OMe})$ $\left.\left(\mathrm{H}_{2} \mathrm{O}\right)_{3}\right]^{+}$with halide ions: effect of halide trans effect on methoxide hydrolysis. Inorg. Chim. Acta, 2003, 352, 201-207.

Hadi S., Appleton T.G. Reactions of cisplatin hydrolytes, cis-[Pt(15NH3)2(H2O)2] 2+, with N-acetyl-L-cysteine. Russ. J. Inorg. Chem., 2010, 55(2), 223-228.

Hadi S., Rilyanti M., Synthesis and in vitro anticancer activity of some organotin(IV) benzoate compounds. Orient. J. Chem., 2010, 26(3), 775-779.

Hadi S., Rilyanti M., Suharso S., In Vitro Activity and Comparative Studies of Some Organotin(IV) Benzoate Derivatives Against Leukemia Cancer Cell: L-1210. Indo. J. Chem., 2012, 12(1), 172-177.

Hadi S., Afriyani H., Anggraini W.D., Qudus H.I., Suhartati T., The Synthesis and Potency Study of Some Dibutyltin(IV) Dinitrobenzoate Compounds as Corrosion Inhibitor for Mild Steel HRP in DMSO-HCI Solution. Asian J. Chem., 2015, 27(4), 1509-1512

Hadi S., Hermawati E., Noviany N., Suhartati T., Yandri, Antibacterial Activity Test of DiphenyltinIV) Dibenzoate and Triphenyltin(IV) Benzoate Compounds against Bacillus substilis and Pseudomonas aeruginosa. Asian J. Microbiol. Biotech. Env. Sci., 2018a, 20(1), 113-119.

Hadi S., Noviany N., Rilyanti M., In Vitro Antimalarial Activity of Some Organotin(IV) 2-Nitrobenzoate Compounds Against Plasmodium falciparum. Macedon. J. Chem. Chem. Eng., 2018b, 37(2), 185-191.

Hadi S., Noviany N., Qudus H.I., Wattana-Amorn P., The Potency Study of Organotin (IV) 3-Nitrobenzoate Compounds as Antimalarial Agents. J. Phys. Conf. Ser., 2019, 1338, 012012.

Hadi S., Lestari S., Suhartati S., Qudus H.I., Rilyanti M., Herasari D., et al., Synthesis and comparative study on the antibacterial activity organotin (IV) 3-hydroxybenzoate compounds. Pure Appl. Chem., 2021, 93(5), 623-628.

Hansch C., Verma R.P., Larvicidal activities of some organotin compounds on mosquito larvae: A QSAR study. Eur. J. Med. Chem., 2009, 44(1), 260-273.

Hazani N.N., Mohd Y., Ghazali S.A.I.S.M., Farina Y., Dzulkifli N.N., Electrochemical Studies on Corrosion Inhibition Behaviour of Synthesised 2-acetylpyridine 4-ethyl-3-thiosemicarbazone and Its Tin(IV) Complex for Mild Steel in $1 \mathrm{M} \mathrm{HCl}$ Solution. J. Electrochem. Sci. Technol., 2019, 10(1), 29-36.

Holeček J., Handlî̃ K., Nádvorník M., Lyčka A., ${ }^{13} \mathrm{C}$ and ${ }^{119}$ Sn NMR study of some triphenyltin(IV) carboxylates. J. Organomet. Chem., 1983, 258 (2), 147-153.

Khoo L.E., Smith F.E., NMR Studies of Triorganotin Aminobenzoates. Inorg. Chim. Acta, 1981, 53, L83-L84.

Kurniasih H., Nurissalam M., Iswantoro B., Afriyani H., Qudus H.I., Hadi S., The Synthesis, Characterization and Comparative Anticorrosion Study of Some Organotin(IV) 4-Chlorobenzoates. Orient. J. Chem., 2015, 31(4), 2377-2383.

Molloy K.C., Blunden S.J., Hill R., Organotin biocides. Part 11. Triphenyltin benzoates: electronic versus steric control of structure. Dalton T., 1988, 5, 1259-1266.
Pellerito L., Nagy L., Organotin(IV) ${ }^{n+}$ complexes formed with biologically active ligands: equilibrium and structural studies, and some biological aspects. Coord. Chem. Rev., 2002, 224(1-2), 111-150.

Rehman W., Badshah A., Khan S., Tuyet L.T.A., Synthesis, characterization, antimicrobial and antitumor screening of some diorganotin(IV) complexes of 2-[(9H-Purin-6-ylimino)]-phenol. Eur. J. Med. Chem., 2009, 44(10), 3981-3985.

Samsuar S., Simanjuntak W., Qudus H.I., Yandri Y., Herasari H., Hadi S., In Vitro Antimicrobial Activity Study of Some Organotin(IV) Chlorobenzoates against Staphylococcus aureus and Escherichia coli. J. Adv. Pharm. Edu. Res., 2021, 11(2), 17-22.

Sandhu G.K., Verma S.P., Moore L.S., Parish R.V., Triorganotin(IV) benzoates and aminobenzoates. J. Organomet. Chem., 1987, 321(1), 15-25.

Sari W., Qudus H.I., Hadi S., The Chemical Reactivity Study of Organotin(IV) 4-aminobenzoates Using Cyclic Voltammetry and Antioxidant Activity Test by the DPPH Method. Rev. Chim., 2020, 71(10), 28-37.

Sudjadi, The Structure Determination of Organic Compounds. Ghalia Publishers, 1985, 45-51 (in Indonesian).

Suhartati T., Yandri, Suwandi J.F., Hadi S., In vitro and in vivo Antiplasmodial Activity of Oxyresveratrol and Artonin E Isolated from Two Artocarpus Plants in Indonesia. Orient. J. Chem., 2010, 26(3), 825-830.

Suhartati T., Epriyanti E., Borisha I., Yandri, Suwandi J.F., Yuwono S.D., et al., In Vivo Antimalarial Test of Artocarpin and in vitro Antimalarial Test of Artonin M Isolated from Artocarpus. Rev. Chim., 2020, 71(5): 400-408.

Swisher R.G., Volcano J.F., Chandrasekhar V., Day R.O., Holmes R.R., Pentacoordinated Structures of Triphenyltin Esters of Anthranilic Acid.; o-(Dimethylamino)benzoic Acid, and p-Aminobenzoic Acid Formed by Intramolecular Carboxylate Group Coordination ${ }^{1,2}$. Inorg. Chem., 1984, 23, 3147-3152

Szorcsik A., Nagy L., Gadja-Schrantz K., Pellerito L., Nagy E., Edelmann E.T., Structural studies on organotin(IV) complexes formed with ligands containing $\{\mathrm{S}, \mathrm{N}, \mathrm{O}\}$ donor atoms. J. Radioanal. Nucl. Chem., 2002, 252(3), 523-530.

Tiekink E.R.T., Structural Chemistry of Organotin Carboxylates: A Review of the Crystallographic Literature. App. Organomet. Chem., 1991, 5(1), 1-23.

Tzimopoulos D., Gdaniec M., Bakas T., Akrivos P.D., Structural elucidation for triorganotin derivatives of 3-amino, 4-amino and 3,5-diaminobenzoate. Crystal structures of triphenyltin 4-aminobenzoate and trimethyl and triphenyltin 3,5-diaminobenzoate. J. Coord. Chem., 2009, 62, 1218-1231.

Tyurin V.Y., Yaouhan W., Prishchenko A.A., Shpakovsky D.B., Gracheva Y.A., Antonenko T.A., et al., Complexes of Organotin Compounds with bis- and Trisphosphonate Derivatives of 2,6-ditertbutylphenol Having Antioxidant Activity. Russ. Chem. Bull., 2015, 64(6), 1419-1429.

WHO, Malaria Profile of Indonesia. 2016; available online: http:// www.who.int/malaria/publications/country-profiles/profile_ idn_en.pdf (access: October 5, 2020)

WHO, Roll Back Malaria program. 2005; available online: https://www. who.int/malaria/publications/atoz/who_htm_mal_2005_1101/ en/ (access: November 6, 2020]

Widyawaruyanti A., Devi A.P., Fatri N., Tumewu L., Tantular I., Hafid A.F., In vitro antimalaria Activity Screening of Several Indonesian Plants Using HRP2 Assay. Int. J. Pharm. Pharmaceut. Sci., 2014, 6, 125-128. 